\title{
Production characteristics of phytoplankton of the Vygozerskoe reservoir (Karelia) under the conditions of reoligotrophization of the ecosystem
}

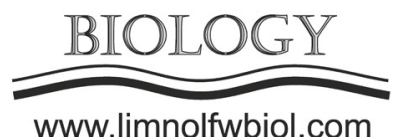

\author{
Tekanova E.V.*, Kalinkina N.M. \\ Northern Water Problems Institute, Federal Research Center "Karelian Research Center RAS"
}

\begin{abstract}
The article presents the results of a study of the phytoplankton production characteristics of the Vygozerskoe reservoir in August 2017 after a 26-year decrease in nutrient load. Photosynthesis is reliably related to water temperature, chlorophyll a, phytoplankton abundance, and the share of green and blue-green algae, Euglenophyta in the community. The values of photosynthesis, the concentration of chlorophyll a and total phosphorus did not exceed the values of 2007-2011, when reoligotrophization was already taking place. These parameters in 2007-2011 and in 2017 corresponded to the natural state of the ecosystem in the early 1970s. Values of chlorophyll a in 2007-2011 and in 2017 remained higher than in the early 1970s. A high share of indicator species of increasing trophic level remains in phytoplankton. We can say that the reoligotrophization of the ecosystem is completed. The persistence of phytoplankton changes may result from an increase in the degree-days of the biological summer because of climate warming in the region.
\end{abstract}

Keywords: Vygozerskoe reservoir, reoligotrophization, photosynthesis, chlorophyll, phytoplankton.

\section{Introduction}

Currently, many freshwater ecosystems are recovering after anthropogenic eutrophication. Vygozerskoe reservoir in Karelia is a naturally oligomesotrophic reservoir, into which wastewater from a pulp and paper mill has been flowing for a long time. The phosphorus content in wastewater increased significantly after the start of biological wastewater treatment in 1976. The ecosystem of the northern part of the reservoir quickly reached a meso-eutrophic state. A decrease in the nutrient load on the aquatic ecosystem began due to the economic crisis in the early 1990s. Previous studies of photosynthesis, chlorophyll $a$, total phosphorus in 2001-2011 showed that reoligotrophization processes took place in the ecosystem. However, in the structure of phytoplankton there were still changes caused by an increase in the trophic level (Tekanova et. all, 2011).

The aim of the study was to assess the current state of the production characteristics of phytoplankton in the Vygozerskoe reservoir after a long decrease in nutrient load.

\section{Material and methods}

The studies were carried out in August 2017 in the surface layer of water. Chlorophyll a in water was determined spectrophotometrically. The rate of photosynthesis was measured by the oxygen flask method. An assimilation factor of 1.25 was taken when converting data to carbon units (Bouillon, 1993).

\section{Results and discussion}

The values of photosynthesis in the water body in August 2017 ranged from 20.4 to $136.3(67.4 \pm 19.7)$ $\mu \mathrm{g}$ C/l-day, the chlorophyll a concentration $-2.8-7.5$ $\mu \mathrm{g} / \mathrm{l}$, total phosphorus - 12-16 $\mu \mathrm{g} / \mathrm{l}$. Higher rates of photosynthesis, concentrations of chlorophyll a and total phosphorus were observed in the southern part of the reservoir, which is strongly influenced by the river inflow, and not in the northern part, which receives wastewater from the pulp and paper mill.

A component data analysis showed that photosynthesis during the study period was independent of the total phytoplankton biomass and the total phosphorus concentration in the water. Factors that reliably intensify the biosynthesis of phytoplankton were the chlorophyll $a$ concentration, water temperature, the total number of phytoplankton and the contribution to the community of chlorophyll-rich green and bluegreen algae, and Euglenophyta. An increase in the community of chrysophyta and dinophytes negatively affected the rate of photosynthesis.

A comparative analysis of the statistical characteristics of the rate of photosynthesis, the

*Corresponding author.

E-mail address: etekanova@mail.ru (E.V. Tekanova)

(C) Author(s) 2020. This work is distributed under the Creative Commons Attribution 4.0 License. 
concentration of chlorophyll $a$ and total phosphorus in 2017 and 2007-2011 showed that medians in 2007 did not exceed the upper limit of the confidence interval for the previous study period.

The values of photosynthesis and the total phosphorus concentration in the Vygozerskoe reservoir from 2007 to the present time correspond to the period of the early 1970s before the development of anthropogenic eutrophication (Vislyanskaya and Kharkevich, 1985). The chlorophyll concentration in water has not changed significantly since the 2000s, when it decreased by almost 4 times compared to the eutrophication period. However, these concentrations remain 3-3.5 times higher than in the early 1970s (Vislyanskaya and Kharkevich, 1985). This discrepancy is caused by changes in the structure of phytoplankton that occurred in the 1980s during eutrophication. In the early 1970 s, more than $95 \%$ of the community were diatoms, and in the $1980 \mathrm{~s}$, this group decreased to $70 \%$. In phytoplankton, the share of highly productive species-indicators of increasing trophic level and organic pollution from blue-green algae, Chlorococcales, Volvocales, and Euglenophyta increased (Tekanova et al., 2011). This phytoplankton composition was preserved in 2007-2011 and in 2017, despite a decrease in quantitative characteristics. The retention over time of these structural changes in the shallow Vygozerskoe reservoir (average depth of 6.2 $\mathrm{m}$ ) can be caused by an increase in the duration of the biological summer by 17 days and thermal content by 307 degrees days as a result of climate warming in the region (Efremova and Palshin, 2015).

\section{Conclusions}

For a long time, the rates of photosynthesis and phosphorus concentrations in the water body are similar to those before anthropogenic eutrophication. This allows us to conclude that the process of reoligotrophization in the Vygozerskoe reservoir is completed. The structure of phytoplankton retains a large proportion of highly productive forms acquired during the eutrophication. This affects the increased concentrations of chlorophyll a and may in the future become a driver for the rapid development of eutrophication under conditions of an increase in the phosphorus load on the water body or intensification of warming.

\section{Acknowledgments}

The study was conducted in accordance with a state assignment given to the Karelian Research Center of the Russian Academy of Sciences (Northern Water Problems Institute, KRC, RAS).

\section{References}

Bouillon V.V. 1993.The radiocarbon method for determining the primary production, its capabilities and limitations compared to the oxygen method. In: Pyrina I.L. (Ed.), Metodicheskiye voprosy izucheniya pervichnoy produktsii planktona vnutrennikh vodoyomov [Methodological issues of studying the primary production of plankton in inland water bodies]. St. Petersburg, pp. 14-20. (in Russian)

Vislyanskaya I.G., Kharkevich N.S. 1985. Phytoplankton of the Vygozerskoe reservoir. In: Vasilieva E.P., Lozovik P.A. (Eds.), Organicheskoye veshchestvo i biogennyye elementy $\mathrm{v}$ vodakh Karelii [Organic matter and nutrients in the waters of Karelia]. Petrozavodsk, pp. 144-165. (in Russian)

Efremova T.V., Palshin N.I. 2015. Long-term variability of water temperature and ice phenology. In: Filatov N.N. (Ed.), Krupneyshiye ozera - vodokhranilishcha Severo-Zapada Yevropeyskoy territorii Rossii: sovremennoye sostoyaniye i izmeneniya ekosistem pri klimaticheskikh i antropogennykh vozdeystviyakh [The largest lakes-reservoirs of the northwest of the European part of Russia: current state and changes of ecosystems under climate variability and anthropogenic impact]. Petrozavodsk, pp. 202-210. (in Russian)

Tekanova E.V., Lozovik P.A., Kalinkina N.M. et al. 2011. Recent state and transformation of the northern part of the Vygozerskoe reservoir. Trudy Karel'skogo Nauchnogo Tsentra Rossiyskoy Akademii Nauk [Transactions of the Karelian Research Center of the Russian Academy of Science] 4: 50-56. (in Russian) 